\title{
Idade ao primeiro parto, intervalo de partos e peso ao nascimento de um rebanho nelore
}

\author{
Age at first calving, calving intervals and birth weight in Nelore \\ (zebu) cattle bred
}

\author{
Maria Luiza Menezes Széchy ${ }^{1}$, Irineu Machado Benevides Filho ${ }^{2}$ e Lucia Moreno de Souza ${ }^{3}$
}

\begin{abstract}
Resumo
Os dados utilizados no presente estudo, referem-se a 129 registros de idade ao primeiro parto (IPP), 789 registros de intervalos de partos (IEP) e a 793 registros de pesos ao nascimento (PN). As médias gerais para IPP, IEP e PN foram respectivamente 1234 dias, 466 dias e 29,4kg. Dos efeitos fixos estudados, tiveram influência significativa sobre a IPP, o quinquênio do parto, sobre o IEP, o ano de nascimento e a ordem do parto sobre o PN, o ano de nascimento e sexo do produto. As estimativas de herdabilidade para IPP, IEP e PN foram, respectivamente: 0,35, 0,08 e 0,05.
\end{abstract}

Palavras-chave: eficiência reprodutiva, nelore, bovinos

\section{Introdução}

O crescimento sistemático da população brasileira, acarreta uma demanda crescente de proteína animal. Com isso, há necessidade de melhorarmos substancialmente a produtividade do rebanho nacional, principalmente, com relação ao desempenho reprodutivo, que é de fundamental importância na taxa de desfrute e na determinação de maior ou menor disponibilidade de animais para seleção.

Em gado de cốrte, é sabido que os índices registrados para as diferentes características que compõem a eficiência reprodutiva, são extremamente baixos e variáveis (Andrade, 1991). Em recente revisão, Benevides Filho (1994) encontrou, para a raça Nelore, uma variação de 35,84 a 56,62 meses para a IPP, de 389,30 a 586 dias para o IEP e de 26,49 a $31,50 \mathrm{~kg}$ para o PN. Sabe-se que a variabilidade no desempenho" de um rebanho, deve ser encarada como uma manifestação fenotípica resultante da interação de fatores genéticos e de meio ambiente. Em geral, as fontes não genéticas de variação consideradas na avaliação do desem-. penho de um rebanho, são: o mês (época) e ano de parição, a ordem do parto, a idade da vaca ao parto e o sexo do produto.
Com o presente trabalho, objetivou-se estudar o desempenho de um rebanho Nelore, considerando as características de idade ao primeiro parto (IPP), intervalo de partos (IEP) e peso ao nascimento (PN).

\section{Material e Métodos}

Os dados analisados, foram obtidos de fichas zootécnicas de rebanho controlado, criado no Estado do Rio de Janeiro, onde foram colhidas informações sobre a vida reprodutiva de 212 matrizes da raça Nelore, no período de 1964 a 1984. Nesse rebanho, os animais eram criados a pasto, havendo suplementação alimentar apenas para os bezerros desmamados. A admissão das fêmeas para a reprodução, era condicionada a um peso mínimo de $350 \mathrm{~kg}$. O principal critério de seleção nesse rebanho, era o peso do bezerro a desmama.

Do modelo, proposto por Harvey (1979), descrito a seguir, obteve-se as médias ajustadas, as medidas de dispersão e análise para estimar a herdabilidade.

$$
\text { Yijk }=m+A i+F j+E i j k
$$

Onde: Yijk = característica estudada

$\mathrm{m}=$ média geral

$\mathrm{Ai}$ = efeito do iésimo touro (fixo ou aleatório) ou da iésima vaca

$\mathrm{Fj}$ = conjunto dos efeitos fixos:

para idade ao primeiro parto (estação e quinquênio do parto)

para intervalo de partos (mês, ano e ordem do parto)

para peso ao nascimento (sexo do produto, mês, ano e ordem do parto)

Eijk = erro aleatório peculiar a cada observação

As decisões estatísticas foram tomadas ao nível de $1 \%$ e/ou $5 \%$.

\footnotetext{
${ }_{1}^{1}$ Professor Assistente do Departamento de Patologia e Clínica Veterinária da Faculdade de Veterinária da Universidade Federal Fluminense. 2 Professor Titular do Departamento de Zootecnia da Fac. Vet. -UFF

${ }^{3}$ Professor Adjunto do Departamento de Zootecnia da Fac. Vet. -UFF
} 
Os componentes de variância necessários para o cálculo do coeficiente de herdabilidade das características estudadas, foram obtidos pelo método dos quadrados mínimos, empregando-se o modelo matemático proposto. Os coeficientes foram estimados a partir das correlações entre meio-irmãos paternos.

\section{Resultados e Discussão}

Idade ao Primeiro Parto

A média geral observada para a idade ao primeiro parto nesse rebanho, foi de 1234 dias, com desvio padrão de 179,24 dias (5,9 meses).

Benevides Filho, (1994), revisando a literatura, encontrou para a raça Nelore uma IPP média de 43,78 meses, com extremos mínimo e máximo de 35,84 a 56,62 meses: Logo, a média de 40,60 meses obtida neste trabalho, apesar de ainda ser elevada, é melhor do que a média da literatura consultada.

A idade ao primeiro parto, é um reflexo direto da taxa de crescimento. Logo, sofre efeito das variações sazonais na produção e qualidade de alimentos. Em nosso estudo, das fontes não genéticas de variação, apenas o quinquênio do parto exerceu influência significativa sobre as variações da IPP $(P<0,01)$. Tais efeitos são, na verdade, reflexo das influências do ano sobre os pesos e ganhos em peso. Nesse caso, as variações observadas na característica, são devidas às diferenças de clima, nas instalações, no manejo, na administração e na constituição genética do rebanho, em cada ano particular. Além disso, na fazenda, o critério adotado para a admissão das fêmeas no ciclo reprodutivo, era o peso mínimo de $350 \mathrm{~kg}$. Esta prática de retardar, premeditadamente, a entrada das fêmeas no processo reprodutivo, permite que as novilhas atinjam uma condição corporal mais adequada na época de reprodução. Contudo, mascara as diferenças genéticas entre os animais.

A não significância do efeito estação do ano em que ocorreu o nascimento, sugere que as novilhas não sofram, após o desmame, ação deletéria das restrições na disponibilidade qualitativa e quantitativa das forrageiras, imposta pela sazonalidade. Realmente, nesse rebanho, a prática de manejo era a de fornecer suplementação somente aos bezerros desmamados, o que explica os resultados.

A estimativa de herdabilidade para a idade ao primeiro parto, foi de 0,35, valor bem próximo aos 0,46 obtidos para a raça Nelore, por Pereira et al. (1991). Embora haja indicações consensuais de que, nos zebus, a IPP elevada seja consequência direta de uma deficiência nutricional, Pereira (1983) e Villares (1984), admitem que os zebuínos sejam naturalmente menos precoces que os bovinos europeus, alcançando o completo desenvolvimento corporal e a maturidade sexual com idades mais avançadas. De qualquer forma, a magnitude da herdabilidade obtida, supõe considerável variação devida aos genes aditivos e indica a possibilidade concreta de se melhorar a IPP por seleção.

Intervalo de Partos

A média geral para esta característica foi de 466 dias, com desvio padrão de 137,34 dias (4,5 meses). Este resul- tado, quando comparado ao IEP médio de 463,74 dias para a raça Nelore (Benevides Filho, 1994), pode ser considerado satisfatório. Entretanto, a variação encontrada neste estudo e naqueles consultados, sugere uma possibilidade de reduzi-lo. Porém, como ele é composto pelo período de serviço e período de gestação - e como o período de gestação é constante, qualquer melhora na característica passa por intervenções no período de serviço. Em geral, essas intervenções atuam no sentido de evitar o atraso do cio pós parto, aumentando-se os níveis de energia nos períodos pré e pós parto e/ou controlando-se a amamentação.

Das fontes de variação de natureza ambiente consideradas, apenas o ano e a ordem do parto exerceram efeitos estatisticamente significativos sobre as variações observadas no intervalo de partos $(p<0,01)$. A influência significativa do ano de parição sobre IEP é, comumente, creditada às variações normais do ambiente entre os anos. A idade da vaca ao parto, aqui medida pela.ordem de parição, tem sido igualmente detectada, pela maioria dos autores, como importante fonte de variação sendo, regra geral, que as primíparas apresentem interpartos mais longos que as multíparas. Notou-se, ainda, uma tendência negativa do IEP sobre as ordens do parto que, à despeito das questões anatômicas e fisiológicas, pode ser explicada ou pelo tamanho da amostra (que tende a diminuir a cada ordem de parição) e/ou pela menor intensidade de seleção das primíparas, quando comparadas com as multíparas, pois é comum o descarte de novilhas com períodos de serviço mais longos.

A baixa estimativa de herdabilidade obtida para o IEP $(0,08)$, está de acordo com os valores encontrados na literatura consultada (Pereira et al., 1991) e nos indica que esta característica é afetada mais por genes de ação não aditiva e pelo meio ambiente. Assim, além da preocupação com o ambiente geral, é necessário criar estratégias que permitam explorar toda a variabilidade genética da característica, possivelmente, com a introdução de linhagens não aparentadas, que propicie a geração de variabilidade devida a dominância e epistasia.

\section{Peso ao Nascimento}

o peso médio ao nascimento, de 793 bezerros, foi de $29,4 \mathrm{~kg}$. A literatura sobre o peso ao nascer de bezerros Nelore (Benevides Filho, 1994) aponta um valor médio de $28,09 \mathrm{~kg}$ com extremos variando entre 26,49 e 31,50kg estando, portanto, esse resultado acima da média da raça.

Das fontes de variação consideradas, apenas os efeitos do sexo do produto $(p<0,01)$ e ano de nascimento $(P<0,05)$ influenciaram significativamente as variações do peso ao nascimento.

Os bezerros machos foram consistentemente mais pesados. Neste particular, admite-se que o maior peso dos machos ao nascimento, seja fruto da ação precoce da testosterona determinando uma taxa metabólica mais acentuada e, também, do período de gestação que, normalmente, é mais longo.

O efeito do mês do nascimento sobre o peso ao nascer se dá, principalmente, no último trimestre da gestação onde 
o crescimento do feto é mais intenso. A não significância do efeito de mês sobre esta característica, sugere que as variações sazonais da qualidade das pastagens não influenciam a habilidade materna das fêmeas evidenciando, talvez, a rusticidade da raça.

Ao contrário de outros estudos (Rosa et al., 1986 e Ayala et al., 1991), o efeito de reprodutor não afetou significativamente as variações do peso ao nascimento. Este resultado foi, até certo ponto, uma surpresa, pois acreditávamos que possíveis diferenças genéticas aditivas entre os touros, estariam sendo repassadas aos fetos. Isto sugere que a variância aditiva seja muito pequena e/ou que exista estreita consanguinidade entre os reprodutores. Realmente, à semelhança dos estudos de Felício (1975), Silva e Pereira, (1985) e Rosa et al., (1987), a estimativa de herdabilidade para o peso ao nascimento foi muito baixa $(0,05)$. Segundo Pereira (1983), as baixas estimativas deste parâmetro têm como causas prováveis: o parentesco entre reprodutores, o uso de reprodutores selecionados, erros de amostragem, pouca variação genética nas raças zebuínas e grande variações ambientes. Além disso, deve ser ressaltado que o peso ao nascer sofre efetiva contribuição do efeito materno. Seguindo-se este raciocínio e supondo-se que a idade da vaca provoque variações na habilidade materna, era de se esperar que a ordem de parição influenciasse significamente o peso ao nascimento, o que não ocorreu.

\section{Abstract \\ Age at first calving, calving intervals and birth weight in Nelore (zebu) cattle bred}

The data used in this study are record from 129 Age at First Calving (AFC), 789 Calving Intervals (CI) and 793 Birth Weight (BW). General means for AFC, Cl, and BW were: 1234 days, 466 days and 29,4kg, respectively. The following fixed effects had significative influence: a) year period of calving on Age at First Calving; b) year of birth and calving order on Calving Intervals; c) year of birth and sex of calf on Birth
Weigth. Estimates for heritability for AFC, $\mathrm{Cl}$ and BW were $0.35,0.08$ and 0.05 , respectively.

Key words fertility, nelore, cattle

\section{Referências Bibliográficas}

ANDRADE, V.J. Manejo alternativo da reprodução em bovinos de corte Cad. Tec. Esc. Vet., Belo Horizonte, n. 6, p. 1-84, 1991.

AYALA, J.M.N., PEREIRA, J.C.C., OLIVEIRA, H.N. Efeitos genéticos e não genéticos sobre características ponderais de duas populaçōes da raça Nelore. Arq. bras. Med. Vet. Zoot. Belo Horizonte, v. 42, n. 1, 1991.

BENEVIDES FILHO, I.M. Estudo dos fatores genéticos e de Ambiente que influenciam o desempenho de um rebanho da raça Nelore. Niterói, 1994. 78p. Tese (Concurso para Professor Titular) - Faculdade de Veternária, Universidade Federal Fluminense.

FELICIO, P.E. Aspectos fenotípicos genéticos e ambientais dos pesos ao nascer, aos 120 e aos 210 dias das raças Nelore, Guzerá e Gir da Estação Experimental de Zootecnia de Sertãozinho. Ribeirão Preto, 1975. 96p. Dissertação (Mestrado) - Faculdade de Medicina de Ribeirão Preto, Universidade de São Paulo.

HARVEY, W.R. User's guide for LSML 76: mixed model least squares and maximum likelihood computer program. Ohio: Ohio State University, 1979. 76p.

PEREIRA, J.C.C., AYALA, J.M.N., OLIVEIRA, H.N. Efeitos genéticos e não genéticos sobre a idade ao primeiro parto e o intervalo entre partos de duas populações da raça Nelore. Arq. bras. Med. Vet. Zoot., Belo Horizonte, v. 42, n. 1, p. 93-102, 1991.

ROSA, A.N., SILVA, L.O.C., NOBRE, P.R.C. Avaliação do desempenho de animais Nelore em controle de desenvolvimento ponderal no Estado do Mato Grosso do Sul, Brasil. Rev. Soc. bras. Zoot., Viçosa, v. 15, n. 6 , p. 515-32, 1986.

ROSA, A.N., NOBRE, P.R.C., EUCLIDES FILHO, K. Desenvolvimento ponderal de animais da raça Nelore variedade mocha: parâmetros genéticos e de ambiente. In: REUNIÄO NACIONAL DA SOCIEDADE BRASILEIRA DE ZOOTECNIA, 24. 1987, Brasilia. Anais, Brasilia: Sociedade Brasileira de Zootecnia, 1987. p. 286.

SILVA, J.S., PEREIRA, C.S.' Efeitos de meio e de herança sobre o peso ao nascimento, aos 90 dias de idade e à desmama (205 dias) de um rebanho Nelore da Zona da Mata de Pernambuco. Arq. bras. Med. Vet. Zoot., Belo Horizonte, v. 37, n. 2, p. 183-203, 1985.

VILLARES, J.B. Zebú e produtividade de bovinos nos trópicos. In: REUNIÄO ANUAL DA SOCIEDADE BRASILEIRA DE ZOOTECNIA, 21. 1984, Belo Horizonte. Anais, Belo Horizonte: Sociedade Brasileira de Zootecnia, 1984. p.205. 